\title{
Accounting and Environment Path for Building Sector
}

\author{
Alireza Soleimani Damaneh ${ }^{1, a}, \mathrm{Xu} \mathrm{Fengju}^{2, \mathrm{~b}}$ and Mohammadreza Soleimani \\ Damaneh $^{3, c}$ \\ ${ }^{1}$ Department of Engineering Management, School of Business Administration, Wuhan University of \\ Technology, China, \\ ${ }^{2}$ Department of Engineering Management, School of Business Administration, Wuhan University of \\ Technology, China, \\ ${ }^{3}$ Iuoshi Road, Wuchang,Wuhan, Hubei 430070,

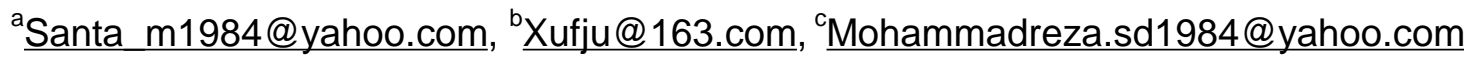

Keywords: Accounting, Environment, Building Sector

Abstract. High-speed economy development has been overtaking the environment and environmental accounting in china. A detailed chart of the integration of different parts of two extensive knowledge (Accounting and Environment) can help greatly to the understanding of the environmental accounting. This chart, synchronized movements of the economy and the environment. This paper strives to make an Accounting- Environment chart for Building sector and explain some of Efficient components of it which are forming environmental science and accounting technique.The high speed of economy development is going to make the face of Chinese cities beautiful only at nights not in days, because the cities' appearance have been fenced by environmental impact during bright days. This study shows the Accounting-Environment chart that demonstrate the way of reaching the objective of this paper, This article will represent the confluence point of Accounting science with the field of environmental engineering, and focus more on the environmental costs which has been ignored in building accounting, hence firstly we can see a hierarchy chart No 1 is about Accounting-Environmental path for building sector. In short, this paper going to make accountants as Environmentalism.

\section{Introduction}

As Accounting and Environment linked is a main objective of this paper therefore, Biodiversity loss and climate change represent two big ecological crises in environment for our living planet at this time. These are inextricably linked. The extremely rapid changes in climate conditions, resulting from global warming, are threatening the integrity of ecosystems around the world. Climate change is projected to be the direct cause of $15-37 \%$ of terrestrial species being committed to extinction by 2050 , depending on the extent of the warming [1]. Conversely, the destruction of natural habitat by humans makes the impacts of climate change worse, as ecosystems are less able to adapt [2]. To achieve a clearer path to a better understanding of the Environmental disaster taking place in science and technology with the help of accounting is available. Accounting is a technical tool for environment which is very important in all aspects of the environment economy. Although it is somewhat remarkable those governments have imposed strict rules but with a sense of responsibility felt in the minds of investors, playing the role of contractors, construction areas, can be reason to comply with strict rules. Floods in South Asia and air pollution in Mumbai and Beijing and high water scarcity and droughts in the Iran crisis is lurking and all are great danger for current and future generations, if politicians, investors, accountants and scientists are not going to cooperate. This paper works at the building sectors because buildings normally have a long life cycle with only limited interaction among stakeholders involved in different phases of a building's lifetime. 


\section{Accounting}

Research question is; What is the relationship between accounting and environment in building sector ? We must confess, nature is excluded from accounting calculation and people are part of nature aren't they? But accounting, like any language, names bounds are thus separates. and accounting is just a language for business for represent the way full of money and according to folks perspective in current generation, money is the most important thing to survive form every good or bad issue, and I think, those who speak this language should have more social responsibility to influence thinking and actions than they perhaps realize or utilize. [3] A considerable percentage of natural resources are often used in building sector, without pricing them or add the price to the economy's price of buildings is impressive issue. However, the prices of resources may not always reflect the cost of renewing renewable resources, nor the full costs of depletion of non-renewable resources [4]. The researcher design an accounting-environmental tree chart for building sector for better understanding the way that paper goes through environment and accounting from root to leaves. Accounting operates within a broad socio-economic environment, and so, the knowledge required of the accountant cannot be sharply compartmentalized. It is therefore, difficult to discuss one area without relating to other areas of knowledge. We place a great emphasis on the conceptual knowledge to mix accounting knowledge with environmental knowledge. From the above it is clear that to define accounting as such, is rather difficult. Many accountants have defined Accounting in very many languages. However, we can consider the following definitions of accounting: Accountancy is the science of recording, classifying and summarizing transactions so that relation with outsiders is exactly determined and result of operation during a particular period can be calculated, and the financial position as the end of the period may be shown. [5]. Accountancy may be defined as the art of recording, classifying and summarizing in a significant manner and in terms of money, transactions and events, which are in part, at least of financial character, and interpreting the results thereof. [6] .Accounting may be defined as the art and science of recording business transactions in a methodological manner so as to show: a). The true state of affairs of a business of a particular period of time, b). The surplus or deficiency which has accrued during a specific period. [7]. According to the author perspective; new definition of Accounting is the technique and rhetoric that explain the financial relationships between the numbers for the best decisions in the domain of Financial management and Environment. Its precise understanding of numbers to help users to make accurate and timely financial or friendly-environmentally, hence a vital part of the healing process is playing by accountants. Accounting has 3 branches such as: Cost, Financial and management accounting therefore Environment has 5 big branches the major field of environmental science are: Biology, Physic Science, Chemistry, Earth science and Social science that in this article the connection area of environment and accounting are 2 fields of 1 . Earth science and Social science: [8]All 3 big branches of Accounting technique and 2 big branches of Environment science have a tight connection with Environmental Accounting in building sector, hence a brief introduction about this 5 branches can help to better understanding of research methodology.

Diagram No 1: Accounting and environment branches;

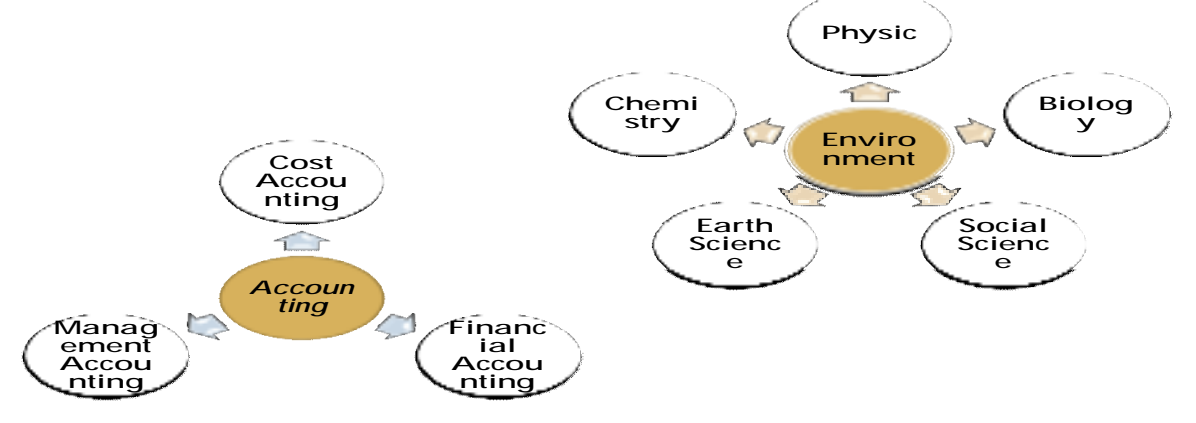


Cost Accounting: This broad branch of accounting has a tight connection with environmental accounting in building sector. CA is a big branch of accounting for manufactures; Cost accounting is a type of accounting process that aims to capture a company's costs of production by assessing the input costs of each step of production as well as fixed costs such as depreciation of capital equipment. Cost accounting will first measure and record these costs individually, then compare input results to output Or actual results to aid company management in measuring financial performance. Cost accounting has 4 type of cost which are: fixed, variable, operating and direct cost.

Management Accounting: The present-day Management is very much dependent on the Accountant and environment in all the levels of managerial and environmental activities. Some functions of MA are: By furnishing regular reports regarding various necessary financial information required daily by the management, the Accountant very ably helps in their work. Cost quality, budgetary and quality Control, Planning etc. MA is a profession that involves partnering in management decision making, devising planning and performance management system, and providing expertise in financial reporting and control to assist management in the formulation and implementation of an organization's strategy. [9]

Financial Accounting: A broad field of accounting that hasn't a close connection with environmental accounting method but FA treats money as a means of measuring economic performance instead of as a factor of production. It encompasses the entire system of monitoring and control of money as it flows in and out of an organization as assets and liabilities, and revenues and expenses. Financial accounting gathers and summarizes financial data to prepare financial reports such as balance sheet and income statement for the organization's management, investors, lenders, suppliers, tax authorities, and other stakeholders. The implication of Wambsganss and Sanford (1996) that a correct financial accounting treatment is determined on the basis of producing economic efficiency is picked up and criticized by Milne (1996).

\section{Environment:}

The second part of study is Environment in Accounting, as we articulate discussed about accounting, environment is a huge science. Environmental science is the study of the environment with a focus on providing solutions to environmental problems such as climate change. Environmental scientists study the earth and work on alternative energy, pollution control and management of natural resources. Building sector is the most dangerous industry for natural resources; China has a large and varied stock of natural resources, including many minerals. China has about 12 percent of the world's mineral resources, with only the United States and Russia possessing larger proportions. [10] and a big percentage of natural resource is used for building sector in China. Green technology helps produce clean energy, make green building sector and reduces Building wastes, and helps a lot to restore the environment. Environmental science incorporates many subjects such as physics, chemistry, mineralogy, limnology, soil science, geology, geography and geodesy but in this paper, environmental science incorporates with Accounting. Here we just discuss a little bit about two branches of Environment Science area which are related and more close to Accounting such as: Earth and Social

Earth science are studying the Geology, which is very important for civil engineeres in building sector . In fact, geology is the study of the Earth's surface, interior processes, and history. Ecology includes conservation, which is a field that seeks to protect organisms from extinction caused by the depletion of natural resources inn building sector. Paleontology is another area that has a indirect relation with building sector which is going to study fossils and ancient life. Climatology is closest areafor building sector that study the Earth's atmosphere and climate. Hydrology most important area for building sector which is study of Earth's water resources. All are earth scincese are related to the building sector and accounting of these areas helps managers to make abest decisions.

Social Science: Geography is the study of the relationship between human populations and Earth's features which is very important to figure out the houses number in a particular area. Anthropology is 
going to describe the economic behaviors of people in particular place or city or country therefore anthropology is going to study the interactions of the biological, cultural, geographical, and historical aspects of humankind. Sociology is the study of human population dynamics and statistics.

\section{Environmental Accounting:}

Environmental accounts are mixed accounts of accounting and environment data that they are a multipurpose data encompassing a conceptual framework and tables which describes the interrelations between the economy and the environment in a way that is consistent with the national accounts. Environmental accounts provide information related to a broad spectrum of environmental and economic issues including, in particular, the assessment of trends in the use of natural resources in building sector, the extent of emissions and discharges to the environment resulting from buildings and construction activities, and the extent of economic activity undertaken for environmental purposes. If we mixed accounting and environment well, we can be used to answer questions such as: Which industry is emitting most greenhouse gases? How do patterns of consumption and production affect the environment? What is the effect of economic policy measures, such as an environmental tax on the generation of waste or air emissions in all business sectors? How fast is the environmental economy growing and how does it compare with the rest of the economy? [11] find the best answer of above question need a clear Accounting -Environment path that shows in chart No,1;

Char No; 1 Accounting-Environment path in Building sector;

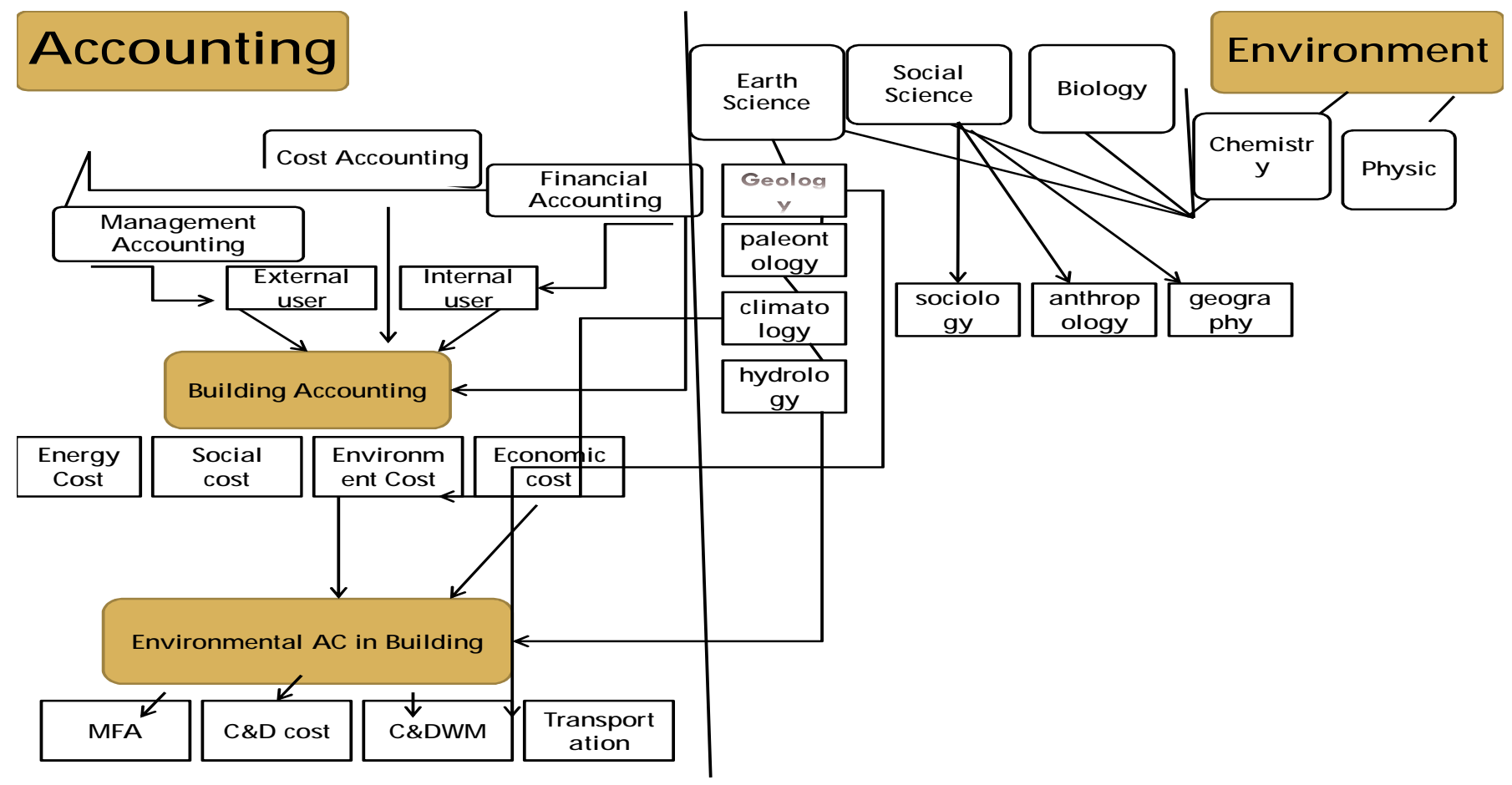

\section{Conclusions}

Integrates of two extensive and old knowledge to meet the financial and environmental concerns in building sector is necessary. This merger, Imposes a heavy financial burden on the shareholders and managers of construction companies. The reason for this is that; building sector benefits do not receive in the short term or current accounting period. Construction industry has a long life hence governments should assist leading companies financially such as subsidy and other ways to make a building sector more green. Accounting and environment are two extensive research environments that require cooperation and collaboration between accountants and environmental experts. The purpose of this research is to identify the path and pores cooperation between the various branches of 
the two sciences. and a big percentage of natural resource is used through building sector hence we need more efficient and green building sector for bright future ahead and to achieve this goal, we do need to mixd accounting and environment. Eart and Social Scince are 2 big branches of Environment scinece and Cost and Financial Accounting are two big branches of Accounting technique hence 2 branches of accounting are add to two branches of environment make relationship between accounting and environment for accountants.

\section{Acknowledgements}

I would like to acknowledge gratefully the efforts of all my professors in Wuhan university of Technology in China and Pune University in India, We also would like to thank the individuals who assisted in the research and/or editing process, including Sanaz Darbalaei and Mohammadreza Soleimani Damaneh.

\section{References}

[1] Thomas, C. D., Cameron, A., Green, R. E., Bakkenes, et al. 'Extinction risk from climate change', Nature, 427, pp. 145-148. (2004)

[2] Naumann, S., Anzaldua, G., Berry, P., Burch, S., Davis, M., Frelih-Larsen, A., Gerdes, H. and Sanders, M. Assessment of the potential of ecosystem-based approaches to climate change adaptation and mitigation in Europe, (2011)

[3] Thomas Cuckston, Financial Accounting Calculation in relation to Nature, Newcastle University Business School February( 2014)

[4] Handbook of National Accounting Integrated Environmental and Economic Accounting An Operational Manual,(2000)

[5] H.Chakravorty,Sumilan.Chakma,Dhaka University The British Institute, Kolkata, Banophool Adibashi Green Heart College, Mirpur, Dhaka.

[6] A.I.C.P.A. the American Institute of Certified Public Accountants (AICPA) is the national professional organization of Certified Public Accountants (1887),

[7] Shearing.A.H, Taylor.H , financial and Cost Accounting for Management, Macdonald and Evans; Fourth Edition edition Germany,(1965)

[8] Holt, Rinehart and Winston. Teaching transparency, Scinece and the environment,(2015)

[9] Institute of Management Accountants, 10 Paragon Drive Montvale, NJ 07645 www.imanet.org

[10] Information on: http://kids.britannica.com/comptons/article-195616/China

[11] eurostat/statistics-explained, information available on; http://ec.europa.eu/eurostat/statistics-explained/index.php/Environmental accounts - establishi ng_the_links_between_the_environment_and_the_economy(2012) 